\title{
Cellular basis of diabetic nephropathy: III. In vitro GLUT1 mRNA expression and risk of diabetic nephropathy in Type 1 diabetic patients
}

\author{
C. Huang 1 Y. Kim ${ }^{1}$ • M. L. Caramori ${ }^{1}$ A. J. Fish ${ }^{1}$ S. S. Rich ${ }^{2}$ M. E. Miller ${ }^{2}$ G. B. Russell ${ }^{2}$ M. Mauer ${ }^{1,3}$ \\ ${ }^{1}$ Department of Pediatrics, University of Minnesota Medical School, Minneapolis, Minnesota, USA \\ 2 Department of Public Health Sciences, Wake Forest University School of Medicine, Winston-Salem, North Carolina, USA \\ ${ }^{3}$ Pediatric Nephrology, University of Minnesota Medical School, Minneapolis, USA
}

\section{Abstract}

Aims/hypothesis. Altered glucose transporter expression has been implicated in the pathogenesis of diabetic nephropathy. There is increasing evidence that genetic factors convey risk of, or protection from, diabetic nephropathy and that the behaviour of cultured skin fibroblasts from Type 1 diabetic patients may reflect these genetic influences. This study aimed to compare GLUT1 mRNA expression levels in skin fibroblasts from Type 1 diabetic patients with either rapid ("fast-track", $n=25$ ) or slow ("slow-track", $n=25$ ) development of diabetic nephropathy and from non-diabetic normal control subjects (controls, $n=25$ ). Methods. Skin fibroblasts were cultured in Dulbecco's Modified Eagle's Medium with $25 \mathrm{mmol} / \mathrm{l}$ glucose for $36 \mathrm{~h}$. Total RNA was isolated, and GLUT1 mRNA levels were estimated by microarray analysis and RT-PCR. Results. Levels of GLUT1 mRNA expression in skin fibroblasts from "slow-track" patients were greater than those from "fast-track" patients $(p=0.02)$, as initially detected by microarray. GLUT1 mRNA expression levels were confirmed by RT-PCR to be higher in

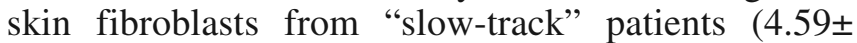
2.04) than in those from "fast-track" patients (3.34 $1.2, p=0.02$ ), and were also higher than in skin fibroblasts from control subjects $(3.52 \pm 1.66, p=0.03)$. There was no statistically significant difference between levels of expression in the "fast-track" patients and the control subjects.

Conclusions/interpretation. This finding is consistent with the presence of cellular protection factors against diabetic nephropathy in the "slow-track" patients. These factors could be associated with the regulation of the GLUT1 pathway and may be genetically determined.

Keywords Cellular marker - Diabetic nephropathy · GLUT1 1 mRNA expression $\cdot$ Skin fibroblasts
Received: 31 January 2004 / Accepted: 12 July 2004

Published online: 22 October 2004

(C) Springer-Verlag 2004

M. Mauer (๘)

Pediatric Nephrology,

MMC 491 University of Minnesota Medical School,

420 Delaware St. S.E., Minneapolis, MN 55455, USA

E-mail: mauer002@umn.edu

Tel.: +1-612-6262720, Fax: +1-612-6262791

Abbreviations: DN, diabetic nephropathy - GBM, glomerular basement membrane $\cdot$ MES, mesangial expansion score $\cdot$ NHE-1, sodium-hydrogen transporter $1 \cdot \mathrm{SNP}$, single-nucleotide polymorphism

\section{Introduction}

Diabetic nephropathy (DN) is the leading cause of end-stage renal disease in the United States [1]. While hyperglycaemia is necessary for the development of DN [1], other variables, especially genetic factors, may strongly influence the response of renal cells to the noxious effects of hyperglycaemia [2, 3]. The clustering of DN in families $[4,5,6]$ and the high concordance for glomerular lesions in Type 1 diabetic sibling pairs [7] support the role of genetic factors in the risk of, or protection from, DN. Moreover, Type 1 sibling pairs concordant for DN lesions [7] are also concordant for skin fibroblast sodium-hydrogen transporter 1 (NHE-1) activity [8], a skin fibroblast marker 
of DN risk $[9,10]$. We recently reported that latent TGF- $\beta$ binding protein- 1 mRNA levels are decreased in skin fibroblasts from Type 1 diabetic patients with slow development of DN compared with those from patients with fast development and those from control subjects [11]. Moreover, the increase in skin fibroblast antioxidant enzyme mRNA, protein and activity in response to high glucose was blunted in patients with DN [12]. Taken together, these studies suggest that skin fibroblast behaviours may reflect DN risk and are probably genetically regulated.

Twelve facilitative glucose transporters have been identified in mammalian cells [13]. GLUT1, which is mainly responsible for non-insulin-dependent glucose transport, is present in almost every tissue and is most abundant in erythrocytes and brain [14]. The GLUT1 $\mathrm{XbaI}(-)$ allele has been associated with the risk of DN in Chinese Type 2 diabetic patients [15] and with protection from DN in Caucasian Type 2 diabetic patients [16]. A study of Mediterranean Type 2 diabetic patients found no association between this allele and DN risk [17]. A single-nucleotide polymorphism (SNP) in the putative enhancer region of GLUT1 (enhancer-2 SNP1) was recently reported to modulate DN risk [18]. It was hypothesised that this polymorphism could influence GLUT1 expression in response to hyperglycaemia and perhaps contribute to genetic susceptibility to DN [18]. However, the association between enhancer-2 SNP1 and the risk of DN has not been confirmed as yet. Thus, a clear association between the GLUT1 polymorphism and the risk of DN remains to be fully established. Nevertheless, in vitro studies have shown that glucose transporters may be important in the development of diabetic nephropathy [19]. The induction of GLUT1 overexpression in rat mesangial cells increases glucose uptake and extracellular matrix production and causes these cells to mimic a "diabetic phenotype" in a normal in vitro glucose environment [20]. In the present study we used microarray screening to assess GLUT1 mRNA expression in skin fibroblasts from Type 1 diabetic patients with rapid and slow rates of DN development. We also measured GLUT1 expression levels using RTPCR in skin fibroblasts from larger groups of Type 1 diabetic patients and non-diabetic control subjects.

\section{Subjects and methods}

Study design and patients. Study design and cohort selection have been reported previously [11, 21]. Briefly, 125 patients with Type 1 diabetes for at least 8 years who had both kidney and skin biopsies, whose serum creatinine values were $\leq 176.8 \mu \mathrm{mol} / 1$ and who had no non-diabetic renal disease were included in this study. All study procedures were approved by the Committee on the Use of Human Subjects in Research at the University of Minnesota.

The 125 patients were ranked by mesangial expansion score (MES), which estimates the rate of development of mesangial expansion [21]. Patients in the highest quintile of the distribution of MES who also had microalbuminuria or proteinuria were classed as "fast-track" patients while those in the lowest MES quintile who were normoalbuminuric were defined as "slow-track". This was done in order to ensure that patients with established DN lesions despite normoalbuminuria were not included in the "slow-track" group. Twelve of the 25 "fast-track" patients received renin-angiotensin system blockade with either angiotensin-converting-enzyme inhibitors $(n=9)$ or angiotensin II receptor blockers $(n=3)$. None of the "slow-track" patients were on these medications. Twenty-five age- and sex-matched kidney transplant donors served as the normal control subjects. Nine of these control subjects had parental histories of hypertension, cardiovascular disease or diabetes.

Ten patients from each of the "fast-track" and "slow-track" groups were used in microarray studies. All 25 subjects in each of the "fast-track", "slow-track" and control groups were included in the study by RT-PCR.

Kidney structure and function studies. Measures of AER, $\mathrm{HbA}_{1} \mathrm{c}$, GFR, blood pressure and renal structural parameters (including glomerular basement membrane [GBM] width, mesangial fractional volume, surface density of peripheral GBM and MES) have been reported previously [21].

Cell culture. Skin fibroblasts, obtained from skin biopsy performed at the kidney biopsy site, were cultured and stored as reported previously [11]. Stored cells were thawed and cultured for three passages in DMEM (Gibco-Life Technologies, Grand Island, N.Y., USA) with $25 \mathrm{mmol} / 1$ glucose, $20 \%$ fetal calf FCS (Hyclone Lab, Logan, Utah, USA), 1.5 mol/l Hepes (Sigma, St Louis, Mo., USA), penicillin (100 U/ml), streptomycin $(100 \mu \mathrm{g} / \mathrm{ml})$ and amphotericin $(250 \mathrm{ng} / \mathrm{ml})$. The 4 th passage skin fibroblasts were seeded in $75-\mathrm{cm}^{2}$ flasks at a density of $10^{4}$ cells per $\mathrm{cm}^{2}$ and grown in DMEM with $25 \mathrm{mmol} / \mathrm{lglu}$ cose and $10 \%$ FCS for $24 \mathrm{~h}$. After being exposed to serum-deprived DMEM medium for $48 \mathrm{~h}$, skin fibroblasts were cultured for an additional $36 \mathrm{~h}$ in the same medium supplemented with $10 \%$ FCS.

RNA isolation. Total RNA was isolated from cultured skin fibroblasts as described previously [11]. The total RNA yield was measured by UV absorbency at $260 \mathrm{~nm}$, and its integrity was evaluated using an Agilent 2100 Bioanalyzer and a RNA 6000 LabChip kit (Hewlett Packard, Palo Alto, Calif., USA). Any degraded samples were discarded and a new sample isolated. Total RNA isolated from the skin fibroblasts of six control subjects cultured in DMEM with $10 \%$ FCS for $72 \mathrm{~h}$ were pooled to generate the standard reference RNA for the RT-PCR assay.

Microarray screening. Affymetrix microarray analyses (Santa Clara, Calif., USA) were carried out following the manufacturer's protocol as described previously [22]. Briefly, total RNA was isolated using Trizol Reagent followed by the RNeasy Mini Kit (Qiagen, Valencia, Calif., USA). Double-stranded cDNAs were prepared from equal amounts of purified total RNA, and biotinylated cRNA was synthesised from the purified cDNA. These cRNA were hybridised to a HuLF 6800 Genechip (containing 6800 genes) using the GeneChip Instrument System (Affymetrix). Normalisation was used in the expression analysis settings to allow comparison between array experiments and groups.

Quantitative RT-PCR. One-step TaqMan real-time RT-PCR was performed as described previously [11] to measure the 
Table 1. Demographic, clinical and glomerular structural characteristics of "fast-track" and "slow-track" Type 1 diabetic patients and control subjects

\begin{tabular}{|c|c|c|c|c|}
\hline Characteristic & "Slow-track" patients & "Fast-track" patients & Control subjects & $p$ value \\
\hline Age (years) & $36.9 \pm 10.6$ & $36.9 \pm 7.4$ & $41 \pm 8$ & NS \\
\hline Age of onset (years) & $15.5 \pm 8.3$ & $13.4 \pm 7.3$ & & NS \\
\hline $\mathrm{HbA}_{1} \mathrm{c}(\%)$ & $\begin{array}{r}8.2 \pm 1.3 \\
(6.0-10.6)\end{array}$ & $\begin{array}{r}9.4 \pm 1.7 \\
(6.5-13.6)\end{array}$ & & $<0.01$ \\
\hline Systolic BP (mm Hg) & $118 \pm 12$ & $131 \pm 13$ & & $<0.001$ \\
\hline $\operatorname{AER}(\mu \mathrm{g} / \mathrm{min})$ & $\begin{array}{c}5.3 \\
(0.4-17)\end{array}$ & $\begin{array}{l}432 \\
(25-4630)\end{array}$ & & NA \\
\hline $\operatorname{GFR}\left(\mathrm{ml} \cdot \mathrm{min}^{-1} \cdot\left[1.73 \mathrm{~m}^{2}\right]^{-1}\right)$ & $\begin{array}{l}113 \pm 12 \\
(85-133)\end{array}$ & $\begin{array}{c}80 \pm 26 \\
(42-143)\end{array}$ & & $<0.001$ \\
\hline GBM width (mm) & $\begin{array}{l}438 \pm 80 \\
(329-669)\end{array}$ & $\begin{array}{l}745 \pm 148 \\
(437-1021)\end{array}$ & & $<0.001$ \\
\hline MES & $\begin{array}{c}0.01 \pm 0.12 \\
(-0.211-0.197)\end{array}$ & $\begin{array}{l}1.49 \pm 0.48 \\
(0.7-2.4)\end{array}$ & & NA \\
\hline
\end{tabular}

Data are means \pm SD (ranges), except those for AER, which are medians (ranges). NA, not applicable (different by study design); $\mathrm{Sv}(\mathrm{PGBM} / \mathrm{glom})$, surface density of peripheral GBM; Vv(Mes/glom), mesangial fractional volume

expression levels of GLUT1. Primers and probes were designed by Primer Express version 1.5 (Applied Biosystems, Warrington, UK), to produce an amplicon spanning an intron. The sequences of the probe and the forward and reverse primers used for the study were: 5'-TGGAGCAACTGTGTGGTCCCTACGTCT-3', 5'-GTGGGCATGTGCTTCCAGTA-3' and 5'-ACAGAACCAGGAGCACAGTGAA-3' respectively. The probe was labelled with 6-carboxyfluorescein (6-FAM) at the $5^{\prime}$ end and 6-carboxy-tetramethyl-rhodamine (TAMRA) at the $3^{\prime}$ end.

The $50 \mu$ l RT-PCR reaction contained $1 \times$ TaqMan Buffer A, $5.5 \mathrm{mmol} / \mathrm{l} \mathrm{MgCl}_{2}, 300 \mu \mathrm{mol} / \mathrm{l} \mathrm{dNTP}, 0.025 \mathrm{U} / \mu \mathrm{l}$ AmpliTaq Gold DNA Polymerase, $0.25 \mathrm{U} / \mu \mathrm{l}$ MultiScribe Reverse Transcriptase, $200 \mathrm{nmol} / \mathrm{l}$ forward and reverse primers, $0.2 \mathrm{U} / \mu \mathrm{l}$ RNase inhibitor and $0.1 \mu \mathrm{g}$ total RNA. After $30 \mathrm{~min}$ at $48{ }^{\circ} \mathrm{C}$ and $10 \mathrm{~min}$ at $95^{\circ} \mathrm{C}$, the amplification reaction was carried out through 40 cycles at $95{ }^{\circ} \mathrm{C}$ for $15 \mathrm{~s}$ and $55^{\circ} \mathrm{C}$ for $60 \mathrm{~s}$. Target mRNAs in unknown samples were quantitated as detailed previously [11]. Briefly, a set of dilutions of the reference total RNA isolated from the skin fibroblasts of six control subjects was used to construct a standard curve and the expression levels of unknown samples were calculated by interpolating their threshold cycle into the regression equation for the standard curve. The relative value of target mRNA in $0.1 \mu \mathrm{g}$ of unknown total RNA sample was expressed as fold changes based on the concentration of target mRNA in $0.1 \mu \mathrm{g}$ of reference total RNA. Multiple quality control strategies for these mRNA measurements, as described earlier, were used [11].

Statistical analysis. The Student's $t$ test was used to compare the demographic, clinical and structural continuous variables between groups, while chi square tests were used for categorical measures. All the investigators except for the statisticians were blinded to the grouping of patients for the gene expression studies. Skin fibroblast mRNA expression levels among the three groups were compared using ANOVA. Comparisons between "fast-track", "slow-track" and control subjects were made using Fisher's Least Significant Differences procedure only if the overall F-test from the ANOVA was significant at a $p$ value of less than 0.05 [23]. To correct for the non-normal distribution of skin fibroblast mRNA levels, the values were logarithmically transformed prior to performing ANOVA.

\section{Results}

All three groups were similar with respect to age and gender, and there were no significant differences in diabetes duration between the 25 "fast-track" and 25 "slow-track" patients (Table 1). "Fast-track" patients had higher $\mathrm{HbA}_{1} \mathrm{c}, \mathrm{AER}$ and blood pressure, and lower GFR than "slow-track" patients. "Fast-track" patients had more advanced glomerular lesions, including increased GBM width and mesangial fractional volume and decreased surface density of peripheral GBM (Table 1).

Gene mRNA expression microarray profiling of skin fibroblasts from 10 "fast-track" and 10 "slowtrack" patients showed that GLUT1 mRNA expression levels were 1.5 times higher in the "slow-track" group ( $835 \pm 334$ vs $541 \pm 88$, Student's $t$ test $p=0.02$ ). RT-PCR revealed differences between the levels of GLUT1 mRNA expression in the skin fibroblasts from the three groups (ANOVA $p=0.04$ ). Expression levels in the "slow-track" patients $(4.59 \pm 2.04)$ were 1.4 and 1.3 times higher than those in the "fast-track" patients $(3.34 \pm 1.2, p=0.02)$ and controls $(3.52 \pm 1.66, p=0.03)$ respectively. There was no statistically significant difference between expression levels in the "fast-track" patients and control subjects ( $p=0.89$ ) (Fig. 1). 


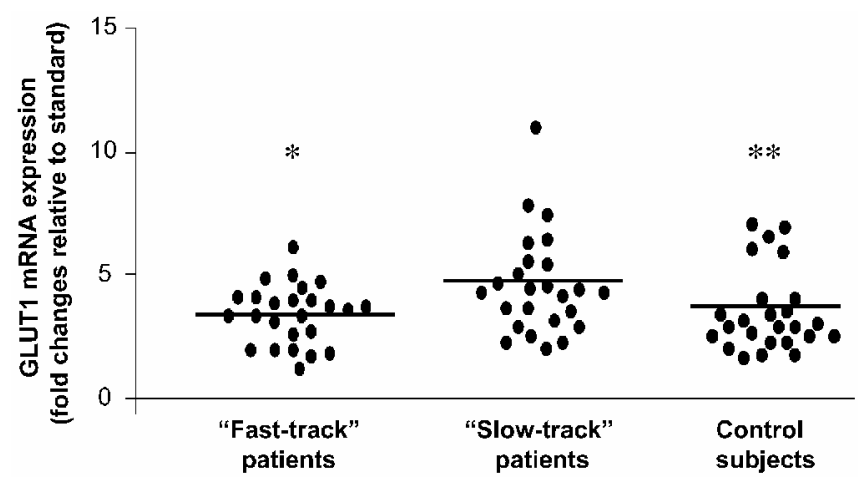

Fig. 1. GLUT1 mRNA expression levels in skin fibroblasts from "fast-track" patients, "slow-track" patients and control subjects. The horizontal bars indicate the mean value for each group. * $p=0.02$ vs "slow-track" patients; ** $p=0.03$ vs "slowtrack" patients

There was no statistically significant difference in skin fibroblast GLUT1 mRNA expression levels between the subgroups of "fast-track" patients who did or did not receive renin-angiotensin system blockade medications $(p=0.83)$. There was no statistically significant relationship between GLUT1 mRNA expression and $\mathrm{HbA}_{1} \mathrm{c}$ levels within the "fast-track" $(r=0.04$, $p=0.83)$ or "slow-track" groups $(r=0.07, p=0.77)$.

Similar GLUT1 mRNA expression levels were found in skin fibroblasts from the control subjects whose parents did $(3.96 \pm 1.58)$ or did not $(3.26 \pm 1.7$, $p=0.11$ ) have histories of hypertension, cardiovascular disease or diabetes.

\section{Discussion}

Why some Type 1 diabetic patients do not develop DN despite long survival is not completely understood $[24,25]$. Recent studies show that, in addition to better glycaemic control, genetic factors probably play crucial roles in the risk or prevention of $\mathrm{DN}$, and these genetic factors may be reflected by the behaviour of cultured cells $[8,9,10,11,12]$. Most previous studies of this type have grouped patients into those with or without clinical findings of DN (i.e. proteinuria). Although patients selected on the basis of proteinuria alone would probably have characteristics similar to our "fast-track" group [26], this may not be the case with our "slow-track" group where both the slow development of DN lesions and normoalbuminuria were required for selection. These criteria were used because several studies have demonstrated that normoalbuminuric patients may have advanced lesions $[21,27,28,29]$ and, despite a long duration of Type 1 diabetes, are still at risk of progression to microalbuminuria and proteinuria [30]. The two groups of Type 1 patients, "fast-track" and "slow-track", included in this study represent the extremes (upper and lower quintiles) of the structural change rate in the 125 re- search subjects from which they were selected. Thus, by selection, despite similar age and Type 1 diabetic duration, the two groups differed with respect to AER. All "slow-track" patients were normoalbuminuric, while four of 25 "fast-track" patients were microalbuminuric and 21 were proteinuric. This strategy of partitioning patients into very high and very low risk and rates of progression of DN lesions was developed in order to maximise the ability of these studies to identify discriminating cellular variables.

The results of this study showed that skin fibroblasts from "slow-track" patients had significantly increased GLUT1 mRNA expression compared with those from "fast-track" patients and normal control subjects, while there was no significant difference between the latter two groups. The differences between the "slow-track" and "fast-track" groups were first identified in microarray studies performed in a small number of subjects from each group and were later confirmed in a larger group of patients by RTPCR, diminishing the likelihood of chance findings. These observations are unlikely to be related to different in vivo environment effects since skin fibroblasts were cultured under identical high glucose conditions for several passages. Moreover, no relationships were observed between GLUT1 mRNA expression and renin-angiotensin system blockade medications or $\mathrm{HbA}_{1} \mathrm{c}$ levels, suggesting that these in vivo conditions cannot explain the observed differences in GLUT1 mRNA expression.

Multiple studies [8, 10, 12, 31, 32] have outlined skin fibroblast cellular markers for Type 1 diabetic patients at increased risk of DN. The present study, along with our previous findings of decreased latent TGF- $\beta$ binding protein- 1 mRNA expression levels in "slow-track" Type 1 diabetic patients compared with "fast-track" patients and control subjects [11], indicates that there are also in vitro cellular behaviours associated with protection from DN. There are no other reports of cellular markers for patients at low risk of $\mathrm{DN}$. The lack of similar findings may be due to the fact that the other studies used less restrictive classification criteria to define the groups investigated. Microalbuminuria is a strong marker for established kidney lesions in Type 1 diabetic patients [30]. However, normoalbuminuric long-standing Type 1 diabetic patients may also have well-established DN lesions and may even have reduced GFR or hypertension [30, 33]. Moreover, approximately $40 \%$ of all patients that progress to proteinuria are normoalbuminuric at initial screening, despite many years of diabetes [30]. "Slowtrack" patients in the present study were selected not only on the clinical basis of normoalbuminuria, but also on the basis of little or no changes in diabetic glomerulopathy in their kidney biopsy tissue as measured morphometrically and adjusted for diabetic duration. Our "slow-track" patients may, therefore, more truly represent the population of patients at very low risk of 
DN, thus increasing the probability of identifying cellular characteristics associated with protection from this condition.

Although this study suggests a possible role of GLUT1 in susceptibility to DN in Type 1 diabetic patients, it is puzzling that skin fibroblasts from the "slow-track" patients have increased GLUT1 expression. Increased GLUT1 expression and GLUT1 activity have been associated with changes in rat mesangial cell functions similar to those induced by high glucose [20, 34, 35]. Our findings might appear to contradict these results; however, it should be noted that our studies do not address GLUT1 protein expression or activity, which may not correspond to gene expression levels. Thus, further studies, including measurements of skin fibroblast GLUT1 protein and activity levels, GLUT1 regulation in renal cells and GLUT1 concordance in sibling pairs concordant for DN risk, could be of substantial interest.

In summary, increased levels of skin fibroblast GLUT1 mRNA expression are associated with protection from DN in Type 1 diabetic patients. Regardless of its pathogenetic significance, this finding could contribute to the development of clinically useful markers for DN risk.

Acknowledgements. C. Huang was supported by a mentorbased research fellowship from the American Diabetes Association. M. L. Caramori was initially supported by the Foundation for the Coordination of Higher Education and Graduate Training (CAPES) from the Brazilian Government and subsequently by a research fellowship grant from Juvenile Diabetes Foundation International. This work was supported by grants from the National Institutes of Health (DK 13083 and DK 54638), the National Center for Research Resources (M01-RR00400) and the Viking Children's Fund (Eden Prairie, Minn., USA). We are especially grateful to P. Walker for his help with the RTPCR. We also thank J. Basgen and T. Groppoli for performing the morphometric studies, K. Pinkham for the cell culture, M. Watrin for patient recruitment and S. Kupcho-Sandberg for AER measurements.

\section{References}

1. The Diabetes Control and Complications Trial Research Group (1993) The effect of intensive treatment of diabetes on the development and progression of long-term complications in insulin-dependent diabetes mellitus. N Engl J Med 329:977-986

2. Krolewski AS, Fogarty DG, Warram JH (1998) Hypertension and nephropathy in diabetes mellitus: what is inherited and what is acquired? Diabetes Res Clin Pract 39 [Suppl]:S1-S14

3. Krolewski AS, Ng DP, Canani LH, Warram JH (2001) Genetics of diabetic nephropathy: how far are we from finding susceptibility genes? Adv Nephrol Necker Hosp 31:295-315

4. Seaquist ER, Goetz FC, Rich S, Barbosa J (1989) Familial clustering of diabetic kidney disease. Evidence for genetic susceptibility to diabetic nephropathy. N Engl J Med 320:1161-1165
5. Borch-Johnsen K, Norgaard K, Hommel E et al. (1992) Is diabetic nephropathy an inherited complication? Kidney Int 41:719-722

6. Quinn M, Angelico MC, Warram JH, Krolewski AS (1996) Familial factors determine the development of diabetic nephropathy in patients with IDDM. Diabetologia 39:940-945

7. Fioretto P, Steffes MW, Barbosa J, Rich SS, Miller ME, Mauer M (1999) Is diabetic nephropathy inherited? Studies of glomerular structure in type 1 diabetic sibling pairs. Diabetes 48:865-869

8. Trevisan R, Fioretto P, Barbosa J, Mauer M (1999) Insulindependent diabetic sibling pairs are concordant for sodiumhydrogen antiport activity. Kidney Int 55:2383-2389

9. Lurbe A, Fioretto P, Mauer M, LaPointe MS, Batlle D (1996) Growth phenotype of cultured skin fibroblasts from IDDM patients with and without nephropathy and overactivity of the $\mathrm{Na}+\mathrm{H}+$ antiporter. Kidney Int 50:1684-1693

10. Trevisan R, Li LK, Messent J et al. (1992) Na+/H+ antiport activity and cell growth in cultured skin fibroblasts of IDDM patients with nephropathy. Diabetes 41:1239-1246

11. Huang C, Kim Y, Caramori ML et al. (2002) Cellular basis of diabetic nephropahty: II. The TGF-b system and diabetic nephropathy lesions in type 1 diabetes. Diabetes 51:3577-3581

12. Ceriello A, Morocutti A, Mercuri F et al. (2000) Defective intracellular antioxidant enzyme production in type 1 diabetic patients with nephropathy. Diabetes 49:2170-2177

13. Joost HG, Bell GI, Best JD et al. (2002) Nomenclature of the GLUT/SLC2A family of sugar/polyol transport facilitators. Am J Physiol Endocrinol Metab 282:E974-E976

14. Klip A, Tsakiridis T, Marette A, Ortiz PA (1994) Regulation of expression of glucose transporters by glucose: a review of studies in vivo and in cell cultures. FASEB J 8:43-53

15. Liu ZH, Guan TJ, Chen ZH, Li LS (1999) Glucose transporter (GLUT1) allele (XbaI-) associated with nephropathy in non-insulin-dependent diabetes mellitus. Kidney Int 55:1843-1848

16. Grzeszczak W, Moczulski DK, Zychma M, ZukowskaSzczechowska E, Trautsolt W, Szydlowska I (2001) Role of GLUT1 gene in susceptibility to diabetic nephropathy in type 2 diabetes. Kidney Int 59:631-636

17. Gutierrez C, Vendrell J, Pastor R et al. (1998) GLUT1 gene polymorphism in non-insulin-dependent diabetes mellitus: genetic susceptibility relationship with cardiovascular risk factors and microangiopathic complications in a Mediterranean population. Diabetes Res Clin Pract 41:113-120

18. Ng DP, Canani L, Araki S et al. (2002) Minor effect of GLUT1 polymorphisms on susceptibility to diabetic nephropathy in type 1 diabetes. Diabetes 51:2264-2269

19. Heilig CW, Brosius FC 3rd, Henry DN (1997) Glucose transporters of the glomerulus and the implications for diabetic nephropathy. Kidney Int Suppl 60:S91-S99

20. Heilig CW, Concepcion LA, Riser BL, Freytag SO, Zhu M, Cortes P (1995) Overexpression of glucose transporters in rat mesangial cells cultured in a normal glucose milieu mimics the diabetic phenotype. J Clin Invest 96:1802-1814

21. Caramori ML, Kim Y, Huang C et al. (2002) Cellular basis of diabetic nephropathy: 1 . Study design and renal structural-functional relationships in patients with long-standing type 1 diabetes. Diabetes 51:506-513

22. Dangond F, Hwang D, Camelo S et al. (2004) Molecular signature of late-stage human ALS revealed by expression profiling of postmortem spinal cord gray matter. Physiol Genomics 16:229-239 
23. Milliken G, Johnson, DE (1984) Analysis of messy data. Designed experiments, vol 1. Van Nostrand Reinhold, New York, p 33

24. Krolewski AS, Warram JH, Christlieb AR, Busick EJ, Kahn CR (1985) The changing natural history of nephropathy in type I diabetes. Am J Med 78:785-794

25. Borch-Johnsen K, Nissen H, Salling N et al. (1987) The natural history of insulin-dependent diabetes in Denmark: 2. Long-term survival-who and why. Diabet Med 4:211-216

26. Mauer SM, Steffes MW, Ellis EN, Sutherland DE, Brown DM, Goetz FC (1984) Structural-functional relationships in diabetic nephropathy. J Clin Invest 74:1143-1155

27. Walker JD, Close CF, Jones SL et al. (1992) Glomerular structure in type-1 (insulin-dependent) diabetic patients with normo- and microalbuminuria. Kidney Int 41:741-748

28. Dalla Vestra M, Saller A, Bortoloso E, Mauer M, Fioretto P (2000) Structural involvement in type 1 and type 2 diabetic nephropathy. Diabetes Metab 26 [Suppl 4]:8-14

29. Chavers BM, Bilous RW, Ellis EN, Steffes MW, Mauer SM (1989) Glomerular lesions and urinary albumin excretion in type I diabetes without overt proteinuria. N Engl J Med 320:966-970
30. Caramori ML, Fioretto P, Mauer M (2000) The need for early predictors of diabetic nephropathy risk: is albumin excretion rate sufficient? Diabetes 49:1399-1408

31. Ng LL, Davies JE, Siczkowski M et al. (1994) Abnormal $\mathrm{Na}+\mathrm{H}+$ antiporter phenotype and turnover of immortalized lymphoblasts from type 1 diabetic patients with nephropathy. J Clin Invest 93:2750-2757

32. Iori E, Marescotti MC, Vedovato M et al. (2003) In situ protein kinase $\mathrm{C}$ activity is increased in cultured fibroblasts from Type 1 diabetic patients with nephropathy. Diabetologia 46:524-530

33. Caramori ML, Fioretto P, Mauer M (2003) Low glomerular filtration rate in normoalbuminuric type 1 diabetic patients: an indicator of more advanced glomerular lesions. Diabetes 52:1036-1040

34. Heilig CW, Liu Y, England RL et al. (1997) D-glucose stimulates mesangial cell GLUT1 expression and basal and IGFI-sensitive glucose uptake in rat mesangial cells: implications for diabetic nephropathy. Diabetes 46:1030-1039

35. Henry DN, Busik JV, Brosius FC 3rd, Heilig CW (1999) Glucose transporters control gene expression of aldose reductase, PKCalpha, and GLUT1 in mesangial cells in vitro. Am J Physiol 277:F97-104 